\title{
FAKTOR DETERMINAN SOSIAL YANG MEMPENGARUHI KEGAGALAN PEMBERIAN ASI EKSKLUSIF DI SRATUREJO, BAURENO, KOTA BOJONEGORO
}

\author{
Social Determinant Factors Affecting The Failure of Exlusive \\ Breastfeeding.in Sraturejo, Baureno, Bojonegoro City
}

\author{
Febriyanti Ramadhani \\ Departemen Promosi Kesehatan dan Ilmu Perilaku Fakultas Kesehatan Masyarakat \\ Universitas Airlangga Surabaya, Jl. Dr. Ir. Soekarno \\ email: febriyanti.ramadhani-2015@fkm.unair.ac.id
}

\begin{abstract}
The breast milk is the best food for babies right for infancy up to 6 months. Breast milk not only benefits the baby, but also brought benefits the mother. Globally, only 38\% of infants aged $0-6$ months are exclusively breastfed. The latest analysis of non-exclusive breastfeeding contributes to $11.6 \%$ of deaths in children under 5 years of age. This is equivalent to around 804,000 child deaths in 2011 (WHO, 2012). This research was conducted to analyze the social determinant factors that affect the failure of Exclusive Breast Feeding in Sraturejo, Baureno, Bojonegoro City. This research was an observational analytic study with a quantitative approach. The research was a cross sectional design. The research was conducted in Sraturejo Village, Baureno, Bojonegoro from 3 July to 9 August 2018. The population were 150 mothers who had children aged 0-24 months. The sample is calculated using the simple random sampling formula which resulted to 110 mothers who have babies 0-24 months of age. The data collection technique used primary data, by filling out the questionnaires of knowledges, attitudes, and behaviors. Then the priority of the problem will be determined using the USG matrix, which the proceeded with finding the cause of the problem with the metaplan technique and a fishbone diagram to identify the root causes of a problem. Then the analysis is conducted with the SWOT method. The results showed no corelation between knowledge and behavior, and there was no corelation between attitude and behavior. Other social determinants discovered are information, methods, economics, environment, individuals, and health. The social determinant factors that most affected the failure of exclusive breastfeeding are economic factors, such as working mothers. The conclusion is that working mothers affected the failure of exclusive breastfeeding.
\end{abstract}

Keywords: exclusive breastfeeding, knowledge, attitude, working women

\begin{abstract}
Abstrak
ASI adalah makanan terbaik bayi sampai berumur 6 bulan. ASI tidak hanya bermanfaat bagi bayi saja, melainkan bermanfaat juga bagi ibu. Secara global, hanya $38 \%$ bayi usia $0-6$ bulan yang mendapat ASI eksklusif. Analisis terbaru pemberian ASI non-eksklusif berkontribusi pada 11,6\% kematian pada anak di bawah usia 5 tahun. Ini setara dengan sekitar 804.000 kematian anak pada tahun 2011. Tujuan penelitian ini adalah untuk menganalisis faktor determinan sosial yang mempengaruhi kegagalan pemberian ASI Eksklusif di Kelurahan Sraturejo Kecamatan Baureno Kota Bojonegoro. Penelitian ini merupakan penelitian observasional analitik dengan pendekatan kuantitatif. Penelitian ini menggunakan rancang bangun cross sectional. Lokasi penelitian dilakukan di Kelurahan Sraturejo Kecamatan Baureno Kota Bojonegoro pada tanggal 3 Juli sampai dengan 9 Agustus 2018. Populasi dalam penelitian ini adalah 150 ibu yang memiliki anak usia 0-24 bulan. Sampel dihitung dengan menggunakan simple random sampling dan di dapatkan 110 ibu yang memiliki bayi 0-24 bulan. Teknik pengumpulan data menggunakan data primer yaitu dengan pengisian kuesioner pengetahuan, sikap, dan tindakan. Kemudian menentukan prioritas masalah menggnakan matriks USG, lalu dilanjutkan dengan mencari penyebab masalah dengan teknik metaplan serta pembuatan diagram fishbone untuk mengidentifikasi akar penyebab dari suatu permasalahan. Kemudian dilakukan analisis dengan metode SWOT. Hasil menunjukkan tidak ada hubungan antara pengetahuan dengan perilaku,
\end{abstract}


dan tidak ada hubungan antara sikap dengan perilaku. Faktor determinan sosial lainnya adalah informasi, metode, ekonomi, lingkungan, individu, dan kesehatan. Faktor determinan sosial yang paling mempengaruhi kegagalan pemberian ASI Eksklusif adalah faktor ekonomi yaitu ibu bekerja. Kesimpulannya adalah ibu bekerja mempunyai pengaruh terhadap pemberian ASI Eksklusif.

Kata kunci: ASI eksklusif, pengetahuan, sikap, ibu bekerja

\section{PENDAHULUAN}

Air Susu Ibu (ASI) merupakan salah satu komposisi nutrisi dalam kolostrum yang dapat membuat anak menjadi cerdas. ASI adalah makanan terbaik bayi sampai berumur 6 bulan. ASI tidak hanya bermanfaat bagi bayi saja, melainkan bermanfaat juga bagi ibu (Purwanti, 2012). Menurut Kementerian Kesehatan tahun 2016 ASI dapat mengurangi tingkat depresi ibu, menurunkan berat badan ibu, mengurangi risiko kanker pada ibu, meningkatkan sistem imun dan perkembangan otak anak menjadi sempurna, mengurangi risiko obesitas pada bayi, serta memperkuat ikatan antara ibu dan anak. Pemberian ASI sejak lahir sampai berumur 6 bulan tanpa pemberian makanan dan minuman tambahan disebut dengan ASI Eksklusif (Roesli, 2008).

Secara global, hanya $38 \%$ bayi usia $0-6$ bulan yang mendapat ASI eksklusif. Analisis terbaru pemberian ASI non-eksklusif berkontribusi pada $11,6 \%$ kematian pada anak di bawah usia 5 tahun. Ini setara dengan sekitar 804.000 kematian anak pada tahun 2011 (WHO, 2011). Berdasarkan hasil Riskesdas 2012 cakupan pemberian ASI eksklusif di Indonesia sebesar 54,3\%, dengan presentase tertinggi yaitu Provinsi NTB sebesar 79,9\%, dan terendah Provinsi Maluku sebesar 25,2\% (Balitbangkes, 2013).

Pemberian ASI Eksklusif telah diatur dalam undang-undang No 36 tahun 2009 tentang Kesehatan Pasal 128 Ayat 2 dan 3 mengenai dukungan pemberian ASI Eksklusif dan Pasal 200 mengenai sanksi pidana jika menghalangi program. Terdapat Peraturan Pemerintah Republik Indonesia Nomor 33 Tahun 2012 tentang Pemberian Air Susu Ibu Eksklusif Pasal 6 yang mengharuskan ibu untuk memberikan ASI Eksklusif pada bayinya, serta Keputusan Menteri Kesehatan Nomor 450/MENKES/SK/VI/2004 tentang Pemberian ASI secara eksklusif di Indonesia. Namun, meskipun telah ditetapkan beberapa kebijakan mengenai ASI Eksklusif masih banyak ibu yang belum memberikan ASI eksklusif pada bayinya (Mufdlilah, 2017).
Terdapat beberapa faktor yang mempengaruhi pemberian ASI eksklusif. Ibu yang memiliki pengetahuan dan sikap baik akan berpeluang lebih besar untuk memberikan ASI eksklusif pada bayinya, dibandingkan ibu yang memiliki pengetahuan dan sikap kurang. Namun, kurangnya produksi ASI ibu dapat membuat ibu tidak memberikan ASI secara eksklusif pada bayinya yang menyebabkan ibu memberikan susu formula pada bayinya (Setyorini et al., 2017). Pengaruh dukungan tenaga kesehatan kadang tidak sesuai dengan harapan keberhasilan ASI eksklusif. Ditemukan bahwa ibu yang kurang mendapat dukungan tenaga kesehatan memiliki kemungkinan untuk tidak memberikan ASI eksklusif sebanyak 10,5 kali lebih besar dari pada ibu yang mendapat dukungan tenaga kesehatan baik (Windari et al., 2017). Terdapat faktor yang menghambat pemberian ASI eksklusif pada ibu pekerja yaitu kurangnya ketersediaan fasilitas, dukungan pengasuh, serta persepsi ibu yang merasa sulit memberikan ASI Eksklusif pada saat kembali bekerja (Abdullah dan Ayubi, 2013).

Pemerintah Indonesia mendukung kebijakan dari WHO dan Unicef yang merekomendasikan inisiasi menyusu dini sebagai tindakan "penyelamatan kehidupan". Hal ini di karenakan inisiasi menyusu dini dapat menyelamatkan $22 \%$ dari bayi yang meninggal sebelum usia satu bulan. Maka dari itu diharapkan semua tenaga kesehatan di semua tingkatan pelayanan kesehatan dapat mensosialisasikan program tersebut (Kemenkes, 2014). Berdasarkan fenomena diatas, maka perlu dilakukan penelitian untuk mengetahui faktor determinan sosial yang mempengaruhi pemberian ASI Eksklusif di Kelurahan Sraturejo Kecamatan Baureno Kota Bojonegoro.

\section{METODE PENELITIAN}

Penelitian ini merupakan penelitian observasional analitik dengan pendekatan kuantitatif yang bertujuan untuk menganalisis faktor determinan sosial yang mempengaruhi kegagalan pemberian ASI Eksklusif di 
Kelurahan Sraturejo Kecamatan Baureno Kota Bojonegoro. Penelitian ini menggunakan rancang bangun cross sectional (Notoatmodji, 2012).

Populasi dalam penelitian ini adalah ibu yang memiliki anak usia 0-24 bulan sejumlah $150 \mathrm{ibu}$. Sampel dihitung dengan menggunakan rumus simple random sampling dengan tingkat kesalahan 5\% yang akhirnya di dapatkan sampel sejumlah 110 ibu yang memiliki bayi 024 bulan. Lokasi penelitian dilakukan di Kelurahan Sraturejo Kecamatan Baureno Kota Bojonegoro pada tanggal 3 Juli sampai dengan 9 Agustus 2018.

Variabel yang diteliti dari variabel independen dalam penelitian ini adalah karaktersitik ibu, pengetahuan ibu dan sikap ibu sedangkan variabel dependen adalah perilaku ibu dalam pemberian ASI Eksklusif. Teknik pengumpulan data menggunakan data primer, yaitu dengan pengisian kuesioner pengetahuan, sikap, dan tindakan. Adapun konten kuisioner meliputi inform consent, karaktertistik responden, dan permasalahan mengenai 1000 HPK.

Dilanjutkan dengan penentuan prioritas masalah menggunakan matriks USG (urgency, seriousness, growth). Matriks USG adalah metode untuk menentukan masalah prioritas dengan melihat faktor atau kriteria yang perlu dipertimbangkan. Kemudian dilanjutkan dengan mencari penyebab masalah dengan teknik metaplan. Metaplan adalah kegiatan diskusi yang bertujuan untuk memperoleh pendapat dari masyarakat, atau partisipan, mengenai suatu masalah secara individu dari masingmasing anggota dan membangun komitmen pendapat atas hasil semua individu sebagai keputusan kelompok.

Kemudian melakukan pembuatan diagram fishbone untuk mengidentifikasi akar penyebab dari suatu permasalahan. Kategorikategori tersebut mencakup ke dalam informasi, metode, ekonomi, lingkungan, individu, dan kesehatan yang berkaitan dengan ASI Eksklusif.

Kemudian dilakukan analisis dengan metode SWOT (strength, weakness, opportunity, dan threat). Metode SWOT adalah alat untuk pengembangan perencanaan dan pengambilan keputusan, serta untuk menganalisis secara sistematis pengelolaan lingkungan internal maupun eksternal organisasi. Metode SWOT menganalisis kekuatan dan kelemahan sebagai komponen internal organisasi, serta menganalisis peluangdan ancaman sebagai komponen eksternal organisasi.

Pengolahan data dilakukan dengan editing, scoring, coding dan entry. Analisis data kuantitatif dengan distribusi frekuensi dari semua variabel untuk mengetahui frekuensinya. Analisis dengan menggunakan uji Chi Square, uji regresi logistik dan mencari faktor determinan sosial.

\section{HASIL DAN PEMBAHASAN}

\section{Hasil}

Gambaran Karakteristik Responden

Dari hasil penelitian didapatkan karakteristik responden dapat dilihat pada tabel 1 sebagai berikut.

Tabel 1. Karakteristik Responden

\begin{tabular}{lcc}
\hline Karakteristik Responden & $\mathbf{N}$ & $(\boldsymbol{\%})$ \\
\hline Umur & & \\
\hline 15-24 tahun & 33 & 30 \\
25-34 tahun & 55 & 50 \\
35-44tahun & 18 & 16,4 \\
45-54 tahun & 4 & 3,6 \\
\hline Pekerjaan & & \\
\hline IRT & 58 & 52,7 \\
Petani & 5 & 4,5 \\
Pedagang & 22 & 20 \\
Swasta & 17 & 15,5 \\
PNS & 6 & 5,5 \\
Lain-lain & 2 & 1,8 \\
\hline Pengetahuan & & \\
\hline Tinggi & 110 & 100 \\
Sedang & 0 & 0 \\
Kurang & 0 & 0 \\
\hline Sikap & & \\
\hline Baik & 110 & 100 \\
Kurang & 0 & 0 \\
\hline
\end{tabular}

Dari Tabel 1 dapat diketahui bahwa sebagian besar responden berumur 25-34 tahun yaitu sebanyak 55 responden (50\%), dan sebagian besar responden menjadi ibu rumah tangga sebanyak 58 responden $(52,7 \%)$. Seluruh responden memiliki pengetahuan tinggi sebanyak 110 responden (100\%) dan sikap baik sebanyak 110 responden (100\%). Dari hasil penelitian didapatkan perilaku pemberian ASI Eksklusif sebagai berikut pada tabel 2.

Tabel 2. Perilaku Pemberian ASI Esklusif

\begin{tabular}{lll}
\hline $\begin{array}{l}\text { Perilaku Pemberian } \\
\text { ASI Eksklusif }\end{array}$ & N & $(\boldsymbol{\%})$ \\
\hline Memberikan & 54 & 49,1 \\
Tidak Memberikan & 56 & 50,9 \\
\hline
\end{tabular}


Tabel 2 menunjukkan bahwa mayoritas responden memberikan susu formula pada anaknya sebelum usia 6 bulan, yaitu sebanyak 54 responden $(49,1 \%)$, sedangkan yang memberikan ASI Eksklusif sebanyak 56 responden $(50,9 \%)$.

\section{Hubungan Umur dengan Pemberian ASI Eksklusif \\ Hasil penelitian dari 110 responden} menunjukkan bahwa mayoritas umur responden antara 25-34 tahun sebanyak 55 orang (50\%). Pada responden yang berumur 25-34 tahun sebanyak 31 orang memberikan ASI Eksklusif $(56,4 \%)$ dan 24 tidak memberikan ASI Eksklusif (43,6\%). Pada responden yang berumur 15-24 tahun sebanyak 14 orang memberikan ASI Eksklusif $(42,4 \%)$ dan 19 orang yang tidak memberikan ASI Eksklusif $(57,6 \%)$. Pada responden yang berumur $35-44$ tahun sebanyak 8 orang memberikan ASI Eksklusif $(44,4 \%)$ dan 10 orang tidak memberikan ASI Eksklusif (9\%). Pada responden yang berumur 45-54 tahun sebanyak 1 orang memberikan ASI Eksklusif (1\%) dan 2 orang tidak memberikan ASI Eksklusif (2\%).

\section{Hubungan Pekerjaan dengan Pemberian ASI Eksklusif}

Hasil penelitian dari 110 responden menunjukkan bahwa mayoritas ibu tidak bekerja atau menjadi ibu rumah tangga. Pada ibu rumah tangga sebanyak 33 orang memberikan ASI Ekskulsif $(56,9 \%)$ dan 25 orang tidak memberikan ASI Eksklusif $(43,1 \%)$. Pada pekerja petani sebanyak 2 orang memberikan ASI Eksklusif (40\%) dan 3 orang tidak memberikan ASI Eksklusif (60\%). Pada pekerja wiraswasta atau pedagang sebanyak 10 orang memberikan ASI Eksklusif (45,5\%) dan 12 orang tidak memberikan ASI Eksklusif $(54,5 \%)$. Pada pekerja swasta sebanyak 7 orang memberikan ASI Eksklusif $(41,2 \%)$ dan 10 orang tidak memberikan ASI Eksklusif $(58,8 \%)$. Pada pekerja PNS sebanyak 3 orang memberikan ASI Eksklusif (33,3\%). Pada pekerja lain-lain seperti perangkat desa tidak ada orang yang memberikan ASI Eksklusif $(0 \%)$ dan 2 orang memberikan ASI Eksklusif $(100 \%)$.

\section{Hubungan Pengetahuan terhadap Pemberian ASI Eksklusi \\ Hasil penelitian menujukkan bahwa} responden yang mempunyai pengetahuan tinggi dan memberikan ASI Eksklusif sebanyak 54 orang $(51 \%)$ dan responden dengan pengetahuan tinggi tetapi tidak memberikan ASI Eksklusif sebanyak 56 orang (49\%). Berdasarkan hasil uji statistik dengan chi square antara variabel pengetahuan dengan variabel pemberian ASI eksklusif diperoleh nilai $p$ value $0,156(>0,05)$, yang artinya tidak ada hubungan yang bermakna antara pengetahuan ibu dengan pemberian ASI eksklusif.

Pertanyaan pengetahuan yang diberikan kepada responden yaitu mengenai 1000 hari pertama kelahiran, tanda-tanda semasa kehamilan, penggunaan tablet $(\mathrm{Fe})$, menyusui bayi, inisiasi menyusu dini, berapa lama pemberian asi eksklusif, manfaat asi eksklusif, penyimpanan asi yang benar, mengenai MPAsi, dan imunisasi.

\section{Hubungan Sikap terhadap Pemberian ASI} Eksklusif

Hasil penelitian menujukkan bahwa responden yang mempunyai sikap baik dan memberikan ASI Eksklusif sebanyak 54 orang (51\%) dan responden dengan sikap baik tetapi tidak memberikan ASI Eksklusif sebanyak 56 orang $(49 \%)$. Berdasarkan hasil uji statistik dengan chi square antara variabel sikap dengan variabel pemberian ASI eksklusif diperoleh nilai $p$ value $0,101(>0,05)$, yang artinya tidak ada hubungan yang bermakna antara sikap ibu dengan pemberian ASI eksklusif.

Sikap adalah respon tertutup baik positif atau negatif yang dimiliki oleh seseorang untuk melakukan suatu perilaku. Sikap pemberian ASI Eksklusif merupakan keyakinan individu bahwa bahwa memberikan ASI Eksklusif dapat memberikan dampak positif bagi kesehatan individu tersebut dan anaknya.

Pernyataan mengenai sikap dinilai dengan pilihan jawaban sangat tidak setuju sampai dengan sangat setuju dengan 10 item pertanyaan mengenai ASI Ekslusif, Insisiasi menyusu dini, imunisasi, dan kembang tumbuh anak.

\section{Pembahasan}

ASI Eksklusif adalah memberikan hanya ASI saja tanpa memberikan makanan dan minuman lain kepada bayi sejak lahir sampai berumur 6 bulan, kecuali obat dan vitamin (WHO, 2011). Menurut Peraturan Pemerintah Republik Indonesia No 33 Tahun 2012 Tentang Pemberian Air Susu Ibu Eksklusif dalam BAB 
III pasal 6 disebutkan bahwa setiap ibu yang melahirkan harus memberikan ASI Eksklusif kepada bayi yang dilahirkannya.

Namun hal ini tidak dilakukan oleh ibu di Kelurahan Sraturejo, menurut hasil penelitian mayoritas responden memberikan susu formula pada anaknya sebelum usia 6 bulan, yaitu sebesar 56 responden $(50,9 \%)$, dibandingkan memberi ASI eksklusif sebesar 54 respoden $(49,1 \%)$.

Penelitian dilaksanakan di Kelurahan Sraturejo, Kecamatan Baureno, Kota Bojonegoro. Berdasarkan hasil penelitian diketahui mayoritas responden yang memberikan ASI Eksklusif berumur 25-34 tahun sebanyak 31 orang $(56,4 \%)$ memberikan ASI Eksklusif. Umur merupakan salah satu background factor yang berpengaruh pada pemberian ASI Eksklusif. Setiap kelompok umur akan memiliki pengetahuan, sikap, dan tindakan yang berbeda dalam pemberian ASI Eksklusif. Hal ini menunjukkan bahwa sebagian besar responden berada pada usia reproduksi sehat (Septyani, 2017).

Menurut hasil penelitian dapat diketahui bahwa mayoritas responden yang memberikan ASI Eksklusif adalah ibu tidak bekerja atau ibu rumah tangga, yaitu sebanyak 33 orang memberikan ASI Ekskulsif (56,9\%). Hal ini dapat dikatakan bahwa ibu yang tidak bekerja memiliki waktu luang untuk memberikan ASI Eksklusif pada bayinya.

Hasil penelitian menujukkan bahwa tidak terdapat hubungan yang bermakna antara pengetahuan ibu dengan pemberian ASI eksklusif. Pengetahuan merupakan hasil dari tahu dan ini terjadi setelah orang melakukan penginderaan terhadap suatu objek tertentu. Sebagian besar pengetahuan manusia diperoleh melalui mata dan telinga (notoat,odjo, 2003). Diharapkan pengetahuan yang baik akan berpengaruh pada sikap dan perilaku yang baik, khususnya dalam pemberian ASI eksklusif. Namun dalam penelitian terdapat 54 responden $(49,1 \%)$ dengan pengetahuan baik yang memberikan ASI Eksklusif, dan 56 responden (50,9\%) memiliki tingkat pengetahuan baik tetapi tidak memberikan ASI eksklusif. Hal ini sesuai dengan penelitian sebelumnya di Puskesmas Bahu Kecamatan Malalayang Kota Manado yang menunjukkan tidak ada hubungan antara pengetahuan responden dengan pemberian ASI ekslusif $(\mathrm{p}=0,185)$ (Mabud et al., 2014). Namun, berbeda dengan penelitian lain yang menyatakan hasil hubungan pengetahuan dan perilaku yaitu $\mathrm{p}=0,05$ yang berarti terdapat hubungan pengetahuan responden dengan pemberian ASI Eksklusif (Setyorini, 2017).

Hasil penelitian menunjukkan bahawa tidak terdapat hubungan yang bermaka antara sikap ibu dengan pemberian ASI eksklusif ( $p=$ 0,101). Sikap merupakan respon tertutup yang dihasilakn oleh individu terhadap stimulus yang diterimanya dengan melibatkan faktor pendapat dan emosi yang bersangkutan untuk setuju atau tidak setuju terhadap suatu perilaku (Notoatmodjo, 2010). Menrut teori apabila sikap seseorang baik maka akan berpengaruh pada perilaku seseorang tersebut (Ajzen, 2005). Namun dalam penelitian terdapat 56 responden $(50,9 \%)$ memiliki sikap yang baik tetapi tidak memberikan ASI eksklusif, sedangkan hanya 54 responden $(49,1 \%)$ yang memiliki sikap baik yang memberikan ASI Eksklusif. Hasil penelitian ini sejalan dengan hasil penelitian yang dilakukan oleh Yulianah dkk (2013) di Wilayah Kerja Puskesmas Bonto Cani Kabupaten Bone yang menunjukkan bahwa tidak terdapat hubungan yang bermakna antara sikap dengan pemberian ASI Eksklusif ( $\mathrm{p}=$ 0,154). Namun, penelitian lain menghasilkan bahwa terdapat hubungan bermakna antara sikap ibu dengan pemberian ASI eksklusif. Semakin positif sikap ibu, semakin besar peluang ibu memberikan ASI eksklusif (Abdullah, 2013).

Perilaku pemberian ASI Eksklusif dapat dilihat juga berdasarakan hasil metode USG dengan melibatkan beberapa perangkat Desa Sraturejo, Kecamatan Baureno, Kabupaten Bojonegoro. Penentuan prioritas masalah dengan metode USG diawali dengan penjelasan mengenai beberapa masalah yang telah ditentukan dari hasil kuisioner. Setelah diberikan penjelasan, perangkat desa diminta untuk memberikan tanggapan pada masingmasing perbandingan masalah. Didapatkan urutan pertama prioritas masalah kesehatan di Desa Sraturejo adalah kurangnya pemberian ASI Eksklusif.

Kemudian dilakukan metaplan untuk melihat penyebab masalah yang dihadiri 12 kader yang membahas mengenai penyebab kurangnya pemberian ASI eksklusif dan alternatif solusi untuk memberikan ASI 
Eksklusif. Hasil dari metaplan didapatkan bahwa kurangnya pemberian ASI eksklusif pada bayi karena ASI ibu yang tidak keluar dan karena ibu bekerja. Ditemukan hasil juga bahwa responden telah menyadari pentingnya ASI eksklusif pada anak, namun masih belum mengetahui solusi terbaik untuk mengatasi kurangnya angka pemberian ASI eksklusif pada anak.

Terdapat penentuan akar penyebab masalah dengan menggunakan diagram fishbone pada masalah kurangnya pemberian ASI Eksklusif. Hasil yang didapatkan dibagi menjadi 6 bagian. Menurut faktor informasi, hal yang membuat ibu tidak memberikan ASI Eksklusif adalah informasi yang diberikan petugas kesehatan stagnan dan kurang menarik dalam penyampaian informasi mengenai pentingnya ASI Eksklusif. Menurut faktor metode, kurangnya informasi mengenai pemberian ASI Eksklusif disebabkan karena media yang kurang menarik yang dikarenakan dana yang kurang mencukupi.

Menurut faktor ekonomi, hal yang membuat ibu tidak memberikan ASI Eksklusif adalah ibu bekerja untuk membantu suami dan menambah penghasilan keluarga. Menurut faktor lingkungan, tidak ada ruang laktasi di tempat kerja karena tidak ada kebijakan di tempat kerja, dan ibu tidak mendukung pemberian Asi Eksklusif karena ada pengaruh tetangga dan adanya persepsi ibu mengenai bayi gemuk itu sehat dengan susu formula.

Menurut faktor individu/ibu, hal yang membuat ibu tidak memberikan ASI Eksklusif adalah menjaga tubuh karena takut payudara kendor, dan kurang kesadaran sehingga tidak ada tindakan nyata. Menurut faktor kesehatan, ASI ibu tidak keluar karena ibu kurang mengonsumsi makanan bergizi dan ibu tidak melatih dan membersihkan payudara saat masa kehamilan.

Berdasarkan hasil analisis SWOT, Desa Sraturejo berada pada kuadran S-T. Hal tersebut menunjukkan bahwa dengan analisis strength posture dengan angka 0,56 menunjukkan nilai strength lebih tinggi dibandingkan dengan nilai weakness.

Nilai strength pada hal ini adalah akses ke Puskesmas mudah dan dekat $( \pm 2 \mathrm{Km})$, memiliki posyandu balita dan lansia, memiliki Ponkesdes, memiliki jumlah kader yang memadai untuk mendukung program KIA/KB, adanya kerja sama yang baik antara para kader dan sejumlah tenaga kesehatan, serta dengan perangkat warga Desa Sraturejo, adanya pemantauan secara berkala dari para kader ataupun tenaga kesehatan, memiliki posyandu/akses sarana prasarana yang mendukung kegiatan $\mathrm{KIA} / \mathrm{KB}$, memiliki tenaga ahli kesehatan di bidang $\mathrm{KIA} / \mathrm{KB}$, dan penyuluhan serta sosialisasi mengenai $\mathrm{P} 2$ sudah berjalan setiap bulan.

Sedangkan pada hasil analisis competitive posture menunjukkan nilai opportunity lebih tinggi dibandingkan dengan nilai threath. Nilai opportunity pada hal ini adalah masyarakat cukup aktif dalam keikutsertaan pada Posyandu, adanya anggaran dana dari Dinas Kesehatan Kabupaten Bojonegoro pada setiap program, adanya balai yang dapat digunakan sebagai tempat pelaksanaan program Posyandu, mudahnya koordinasi dengan tokoh masyarakat sehingga lebih mudah dalam kerja sama terkait program $\mathrm{KIA} / \mathrm{KB}$, banyaknya aktivitas warga sehingga dapat disampai materi terkait KIA/KB pada pengajian, PKK, ataupun perkumpulan dari kepala keluarga, dan masyarkat aktif dalam setiap kegiatan yang diselenggarakan oleh dasawisma/RT/RW. Dapat dikatakan bahwa Desa Sraturejo memiliki potensi untuk dapat merubah kebiasaan warganya, akan tetapi terdapat ancaman yaitu masyarakat Desa Sraturejo yang susah untuk menerapkan.

Melihat variabel yang terdapat pada pemberian ASI Eksklusif, dan melihat langkahlangkah yang dilakukan untuk menentukan faktor yang menyebabkan ibu tidak memberikan ASI Eksklusif, terdapat hasil yang dapat disimpulkan. Dapat diketahui bahwa di Desa Sraturejo, faktor pengetahuan dan sikap bukan menjadi penyebab ibu tidak memberikan ASI Eksklusif. Melainkan petugas kesehatan yang kurang memberikan informasi meskipun pengetahuan ibu sudah baik, ibu yang bekerja, ibu yang menjaga kondisi tubuh agar tetap ideal, dan ASI ibu yang tidak keluar. Dari 4 faktor tersebut, faktor yang paling mempengaruhi adalah ibu yang bekerja. Seharusnya ibu bekerja tidak memutus kemungkinan untuk memberikan ASI Eksklusif pada bayinya, karena ibu edapat melakukan perah ASI sebelum berangkat bekerja dan di letakkan dalam botol kaca. Kemudian dimasukkan ke lemari pendingin (Mufdlilah, 2017). Diharuskan juga setiap tempat kerja menyediakan fasilitas menyusui di tempat kerja atau ruang laktasi sesuai dengan Permenkes No 15 Tahun 2013 pasal 6 yang menyebutkan bahwa setiap pengurus tempat kerja harus 
memberikan kesempatan bagi ibu bekerja untuk menyusui atau memerah ASI pada waktu kerja di tempat kerja, dan dengan adanya penyediaan ruang ASI sesuai standar.

\section{KESIMPULAN DAN SARAN}

\section{Kesimpulan}

Karakteristik responden sebagian besar berumur 24-34 (50\%), sebagian besar bekerja sebagai ibu rumah tangga $(56,9 \%)$, seluruh reponden memiliki pengetahuan baik $(100 \%)$, dan seluruh responden memiliki sikap baik $(100 \%)$. Tidak ada hubunga antara pengetahuan dengan perilaku, dan sikap dengan perilaku. Adanya faktor lain yang didapatkan melalui pencarian priorias masalah menggunakan teknik metaplan dan diagram fishbone sebagai penyebab kegagalan ibu memberikan ASI Eksklusif yaitu faktor informasi, metode, ekonomi, lingkungan, indvidu dan kesehatan. Faktor yang paling mempengaruhi kegagalan pemberian ASI Eksklusif adalah faktor ekonomi yaitu ibu bekerja.

\section{Saran}

Sesuai hasil kesimpulan yang di dapatkan yaitu ibu bekerja menjadi faktor yang paling berpengaruh terhadap kegagalan pemberian ASI Ekskusif. Telah terdapat kebijakan yang telah diterapkan di Indonesia mengenai ASI Eksklusif baik peraturan maupun sanksi. Diharapkan, terdapat ruang laktasi di setiap perusahaan dan terdapat kebijakan di perusahaan untuk memberikan waktu luang untuk ibu memberikan ASI Eksklusif kepada anaknya maupun memompa ASInya. Ibu bekerja juga diharapkan dapat mempersiapkan jadwal yang pasti untuk memompa ASI. Hal yang dapat dilakukan yaitu dengan mempersiapkan alat pompa ASI di malam hari, kemudian di pagi hari ibu dapat langsung memompa ASInya dan disimpan di freezer. ASI yang disimpan di freezer masih memiliki lebih banyak antibodi dan gizi yang tepat untuk bayi dibandingkan dengan susu formula.

\section{DAFTAR RUJUKAN}

1] Abdullah, G. I., \& Ayubi, D. (2013). Determinan Perilaku Pemberian Air Susu Ibu Eksklusif Pada Ibu Pekerja. Jurnal Kesehatan Masyarakat Nasional Vol. 7, No. 7, , 298-303.
2] Ajzen, I. (2005). Attitudes, Personality, And Behavior 2nd Ed. USA: Mcgrawhill.

3] Balitbangkes. (2013). Riset Kesehatan Dasar 2012. Jakarta: Badan Penelitian dan Pengembangan Kesehatan Departemen Kesehatan Republik Indonesia.

4] Mabud, N. H., Mandang, J., \& Mamuaya, T. (2014). Hubungan Pengetahuan, Pendidikan, Paritas Dengan Pemberian ASI Eksklusif Di Puskesmas Bahu Kecamatan Malalayang Kota Manado . JIDAN Volume 2 Nomor 2. ( ISSN : 2339-1731 ), 51-56.

5] Mufdlilah. (2017). Kebijakan Pemberian Asi Eksklusif: Kendala Dan Komunikas. Yogyakarta: Nuha Medika

6] Notoatmodjo, S. (2003) Ilmu Kesehatan Masyarakat Prinsip-Prinsip Dasar, Jakarta: Rineka Cipta. Jakarta.

7] Notoatmodjo, S. (2010) Promosi Kesehatan, Teori \& Aplikasi, ed. revisi 2010, Jakarta: Rineka Cipta. Jakarta.

8] Notoatmodjo, S. (2012). Metodologi Penelitian Kesehatan. Jakarta: Rineka Putra.

9] Profil Kesehatan Republik Indonesia Tahun 2013. (2014). Jakarta : Kementrian Kesehatan Republik Indonesia

10] Purwanti, H. S. (2012). Konsep Penerapan ASI Eksklusif : Buku Saku Bidan. Jakarta: Buku Kedokteran EGC.

11] Roesli, U. (2008). Panduan Inisiasi Menyusui Dini. Jakarta: Pustaka Bunda.

12] Septyani, H., Budi, A., \& Karbito. (2017). Faktor-Faktor yang Berhubungan dengan Pemberian ASI Eksklusif Oleh Ibu Menyusui yang Bekerja Sebagai Tenaga Kesehatan. Jurnal Ilmu Kesehatan Volume 2 Nomor 2. (ISSN : 2502-4825), 160-174.

13] Setyorini, R. N., Widjanarko, B., \& Sugihantono, A. (2017). Faktor-Faktor Yang Mempengaruhi Perilaku Pemberian Air Susu Ibu (ASI) Eksklusif Di Wilayah Kerja Puskesmas Pegandan Kota Semarang. Jurnal Kesehatan Masyarakat Volume 5, Nomor 3 (Issn: 2356-3346) , 620-628.

14] World Health Organization [WHO]. 2011. Breastfeeding counseling: A training course. UNICEF 
15] Windari, E. N., Dewi, A. K., \& Siswanto. (2017). Pengaruh Dukungan Tenaga Kesehatan Terhadap Pemberian Asi Eksklusif Di Wilayah Kerja Puskesmas Sisir Kelurahan Sisir Kota Batu. Journal of Issues In Midwifery Vol 1, No 2, 19-24. 